\title{
Lying times of lactating cows on dairy farms with automatic milking systems and the relation to lameness, leg lesions, and body condition score
}

\author{
R. Westin, ${ }^{\star 1}$ A. Vaughan, ${ }^{*}$ A. M. de Passillé, ${ }^{*}$ T. J. DeVries,† E. A. Pajor,‡ D. Pellerin,§ J. M. Siegford,\# \\ E. Vasseur,ll and J. Rushen* \\ *UBC Dairy Education and Research Centre, University of British Columbia, Agassiz, British Columbia, Canada, V0M 1A0 \\ †Department of Animal Biosciences, University of Guelph, Guelph, Ontario, Canada, N1G 2W1 \\ fDepartment of Production Animal Health, University of Calgary, Calgary, Alberta, Canada, T2N 4N111 \\ §Department of Animal Science, Universite Laval, Quebec, Quebec, Canada, G1V 0A6 \\ \#Department of Animal Science, Michigan State University, East Lansing 48824 \\ IIDepartment of Animal Science, McGill University, Sainte-Anne-de-Bellevue, Quebec, Canada, H9X 3V9
}

\begin{abstract}
Lying down and resting are important for optimal cow health, welfare, and production. In comparison with free stall farms with a milking parlor, farms with automated milking systems (AMS) may place less constraint on how long cows can lie down. However, few studies report lying times on AMS farms. The aims of this study were to describe the variation in lying times of dairy cows in AMS farms and to understand how much of the variation in individual lying times is related to cow-level factors, including lameness, the presence of hock and knee lesions, and body condition score (BCS). We visited 36 farms in Canada (Quebec: $\mathrm{n}=10$; Ontario: $\mathrm{n}=10$; British Columbia: $\mathrm{n}=4$; and Alberta: $\mathrm{n}=5$ ), and the United States (Michigan: $\mathrm{n}$ $=7$ ). Gait scores, presence of hock and knee lesions, and BCS were recorded for 40 Holstein cows from each herd. Parity and days in milk were retrieved from farm records. Lying time was recorded across $4 \mathrm{~d}$ using accelerometers $(\mathrm{n}=1,377)$. Multivariable analysis was performed. Of scored cows, $15.1 \%$ were lame (i.e., obviously limping; 203 of 1,348 cows). Knee lesions were found in $27.1 \%$ (340 of 1,256 cows) and hock lesions were found in $30.8 \%$ (421 of 1,366 cows) of the animals. Daily lying time varied among cows. Cows spent a median duration of $11.4 \mathrm{~h} / \mathrm{d}$ lying down (25th-75th percentile $=9.7-12.9 \mathrm{~h}$ ), with a lying bout frequency of 9.5 bouts $/ \mathrm{d}(25 \mathrm{th}-75$ th percentile $=7.5-12$ bouts $/ \mathrm{d})$ and a median bout duration of $71 \mathrm{~min}$ (25th-75th percentile $=58-87 \mathrm{~min} /$ bout $)$. Lameness was associated with cows lying down for $0.6 \mathrm{~h} / \mathrm{d}$ longer in fewer, longer bouts. Increased lying time was also associated with increased parity, later stage of lactation and higher BCS.
\end{abstract}

Received April 22, 2015

Accepted September 8, 2015.

${ }^{1}$ Corresponding author: rebecka.westin@slu.se
Older cows (parity $\geq 3$ ) spent about $0.5 \mathrm{~h} / \mathrm{d}$ more lying down compared with parity 1 cows, and cows with BCS $\geq 3.5$ lay down on average $1 \mathrm{~h} / \mathrm{d}$ longer than cows with BCS $\leq 2.25$. Hock lesions were associated with shorter lying times in univariable models, but no associations were found in the multivariable models. We concluded that only a small proportion of the variation between cows in lying time is explained by lameness, leg lesions, and BCS.

Key words: automated milking system, hock lesions, injury, knee lesion

\section{INTRODUCTION}

Lying down and resting are important for optimal cow health, welfare, and production (Munksgaard and Simonsen, 1996; Munksgaard et al., 2005), and longer lying times are hypothesized to reflect better welfare (Jensen et al., 2005). However, if cattle lie down for a long time, this may also reflect problems changing position, or lameness (Jensen et al., 2005). Cows seem to be highly motivated to lie down for 12 to $13 \mathrm{~h} / \mathrm{d}$ in indoor housing (Jensen et al., 2005; Munksgaard et al., 2005), and when access to feed or lying areas is restricted, lying time has been shown to have a higher priority than eating time and social contact (Munksgaard et al., 2005). A minimum lying time of $12 \mathrm{~h} / \mathrm{d}$ is therefore recommended under the Canadian Code of Practice for Dairy Cattle (DFC-NFACC, 2009). In freestall herds with a milking parlor, the cows' time budget may be disrupted and lying time decreased as cows are brought as a group to a holding pen where they must stand waiting before milking (Charlton et al., 2014). In AMS farms, cows may have more freedom to control their own time budget, possibly resulting in more undisrupted rest. On the other hand, cows in AMS herds have fewer synchronized behaviors (Wagner-Storch and Palmer, 2003), which may create disruptions when individual cows are moving to and from the resting area 
at all times throughout the day. For cows to access the AMS, a considerable amount of time can also be spent queuing in the waiting area, limiting the time available for rest, especially for low-ranked cows (Melin et al., 2006; Halachmi, 2009) and cows with a high milking frequency (Helmreich et al., 2014).

Studies on commercial non-AMS farms show a large variation between cows and between farms in how long cows lay down (Ito et al., 2009; Charlton et al., 2015), and to use measures of lying time to assess animal welfare, it is important to understand the causes of this variation. Some of the variation may result from lameness or leg injuries. In non-AMS free-stall farms, lameness is associated with a longer time that cows spend lying down (e.g., Chapinal et al., 2009; Ito et al., 2010), whereas in tie-stall farms, an association is also present between shorter lying time and the presence of leg lesions (Charlton et al., 2015). However, little is known of the relationship between lying time and lameness or leg lesions in AMS farms. One key to successful robotic milking is voluntary attendance. Lameness reduces visits to the milking unit (Borderas et al., 2008; Miguel-Pacheco et al., 2014), and lame cows are manually brought to the milking unit more often, which increases labor requirements (Bach et al., 2007). Thus, it is important to understand the factors that affect lying time and the relationship between lying time, lameness, and leg lesions on AMS farms. In addition, lameness has been found to be associated with low BCS (Green et al., 2014; Randall et al., 2015), but a possible association between BCS and lying time has to our knowledge not yet been reported.

Our objectives were to describe the variation in lying times of dairy cows in AMS farms and to understand how much of the variation in individual lying times is related to cow-level factors, including lameness, the presence of hock and knee lesions, and BCS.

\section{MATERIALS AND METHODS}

The study was approved by the Institutional Animal Care Committees and Research Ethics Boards at Laval University, the University of Guelph, the University of Calgary, and Michigan State University.

\section{Herd Selection}

Between April 2011 and November 2012, we visited 36 farms with an automated milking system (AMS) in Canada (Quebec: $\mathrm{n}=10$; Ontario: $\mathrm{n}=10$; British Columbia: $\mathrm{n}=4$; and Alberta: $\mathrm{n}=5$ ), and the United States (Michigan: $\mathrm{n}=7$ ). Farms had to have at least 40 Holstein milking cows and to have operated the AMS for at least 6 mo. Farms were invited by mail to participate in the study, with the number of farms based on an expected positive response rate of $20 \%$. When letters were returned indicating the willingness to participate, the producers were interviewed by telephone to determine if they met the additional study inclusion criteria, which included having cows stallhoused in their present barn for at least $1 \mathrm{yr}$, and no access to outdoor exercise area or pasture for milking cows. The mean $( \pm \mathrm{SD})$ number of milking cows in the participating farms was $155 \pm 105$ (range 42-495 cows) and the mean annual milk production was 9,346 \pm 772 $\mathrm{kg}$ [retrieved from Valacta (Sainte-Anne-de-Bellevue, Quebec, Canada) and CanWest DHI Herd Recording data (Guelph, Ontario, Canada), which were available for 17 farms]. The characteristics of the AMS farms are shown in Table 1.

\section{Cow Selection}

Based on previous work on representative sample sizes for lying time (Vasseur et al., 2012), we selected

Table 1. Description of the automated milking system (AMS) characteristics on participating farms $(\mathrm{n}=36)$

\begin{tabular}{llrr}
\hline \multirow{2}{*}{ Item } & Level & $\begin{array}{c}\text { Number } \\
\text { of farms }\end{array}$ & $\%$ \\
\hline Type of system & Free traffic & 28 & 78 \\
\multirow{2}{*}{ Number of AMS units } & Forced traffic & 8 & 22 \\
& 1 & 18 & 50 \\
& 2 & 11 & 31 \\
Number of cows per unit & 3 & 3 & 8 \\
& 4 & 2 & 6 \\
& 8 & 2 & 6 \\
Brand of AMS & $\leq 40$ & 5 & 14 \\
& $41-50$ & 8 & 22 \\
& $51-60$ & 12 & 33 \\
& $\geq 61$ & 11 & 31 \\
& DeLaval (Tumba, Sweden) & 15 & 42 \\
& Lely (Maassluis, the Netherlands) & 20 & 56 \\
& Other & 1 & 3 \\
\hline
\end{tabular}


Table 2. Parity, stage of lactation, and BCS of the 1,418 cows included in the study

\begin{tabular}{lccc}
\hline \multirow{2}{*}{ Variable } & Level & $\begin{array}{c}\text { Number } \\
\text { of cows }\end{array}$ & $\%$ \\
\hline Parity & 1 & 440 & 34 \\
& 2 & 403 & 31 \\
& $\geq 3$ & 460 & 35 \\
Month of lactation & Data missing & 115 & - \\
& 1 & 147 & 11 \\
& 2 & 222 & 17 \\
& 3 & 217 & 16 \\
4 & 201 & 15 \\
& 5 & 126 & 10 \\
BCS & $6-7$ & 201 & 15 \\
& $\geq 8$ & 210 & 16 \\
& Data missing & 94 & - \\
2 & 18 & 1 \\
& 2.25 & 177 & 13 \\
& 2.5 & 393 & 28 \\
& 2.75 & 214 & 15 \\
3.0 & 244 & 17 \\
& 3.25 & 175 & 12 \\
& 3.50 & 90 & 6 \\
& 3.75 & 58 & 4 \\
& $4.0-4.5$ & 44 & 3 \\
& Data missing & 5 & - \\
\hline
\end{tabular}

40 Holstein focal cows from each herd. Where possible, we maximized the number of focal cows that were between 10 and 120 DIM because this period has been shown to be associated with increased odds of hock and knee injury (Kielland et al., 2009). If the milking herd had less than 40 cows between 10 and 120 DIM, the selection criterion was increased above 120 DIM until a sample of 40 cows was obtained. The sample of focal cows was also chosen to reflect the ratio of primiparous:multiparous cows in the herd. On 5 farms, less than 40 lactating cows were available. In these cases, all cows were selected (range 25-39 cows). We obtained data from a total of 1,418 cows (Table 2).

\section{Animal-Based Measures}

Each farm was visited twice over an interval of 5 to $10 \mathrm{~d}$. In total, 12 assessors collected data on the different farms, but never more than 2 assessors were present per visit and each assessor took the same measures on all cows on a farm. To ensure high repeatability, all assessors had taken part in the same training program before the study started, which is described in detail by Gibbons et al. (2012) and Vasseur et al. (2013). Briefly, the assessors underwent an intensive training program and the repeatability for each assessors was assessed against 2 standard trainers, with only assessors that reached the target $\mathrm{K}_{\mathrm{w}} \geq 0.6$ being used (Gibbons et al., 2012). Once field data collection was in progress, the trainees were re-assessed twice (refresher course 3-4 weeks after initial training and a mid-way assessment) to ensure that they remained objective and repeatable in their scoring.

The parity and DIM of each focal cow were recorded from farm records. All focal cows were assessed for lameness, for the presence of lesions on the hock (tarsus joint) and knees (carpal joints), and for BCS during the first farm visit. Standard operating procedures were used for each animal-based measure as described by Vasseur et al. (2015) and are available on the Canadian Dairy Research Portal (https://www.dairyresearch.ca/ cow-comfort.php\#self). Briefly, cows were scored for hock and knee injuries according to the criteria described by Gibbons et al. (2012) and Zaffino Heyerhoff et al. (2014; Table 3). Both the left and right limbs were scored for hock and knee injuries on a 4-point scale (0 to 3 ; Table 3 ). The BCS were recorded while cows were head-locked at the feed bunk using a 5-point scale in 0.25 increments using the Elanco Animal Health body condition scoring chart for dairy cattle (Elanco Animal Health, 1996), based on Wildman et al. (1982) and Ferguson et al. (1994) and adapted by Vasseur et al. (2013). To identify lame cows, all focal cows were individually video recorded by one of the observers. Video recording took place in the feeding alley where cows were filmed walking after releasing them one at a time from the head lock. This was done after all other measures had been taken during the first farm visit. From observing the videos, cows were later scored for whether they showed a "head bob," "asymmetric stepping" or had an "obvious limp" defined as "uneven weight bearing of one or more limbs," adapted from Flower and Weary (2006).

To record the time the cows spent lying down, accelerometers were attached to the hind leg of each cow. On

Table 3. Scoring scale for carpal and tarsal joint injury in dairy cattle (Gibbons et al., 2012)

\begin{tabular}{lllll}
\hline Item & Score 0 & Score 1 & Score 2 & Score 3 \\
\hline Tarsal joint & $\begin{array}{l}\text { No swelling. No hair is } \\
\text { missing. Thinning of hair or } \\
\text { broken hair. }\end{array}$ & $\begin{array}{l}\text { No swelling or minor } \\
\text { swelling }(<1 \mathrm{~cm}) . \text { Bald } \\
\text { area on hock. }\end{array}$ & $\begin{array}{l}\text { Medium swelling }(1-2.5 \mathrm{~cm}), \\
\text { lesion on bald area, or both. }\end{array}$ & $\begin{array}{l}\text { Major swelling }(>2.5 \mathrm{~cm}) . \\
\text { May have bald area/lesion. }\end{array}$ \\
& No skin change. & $\begin{array}{l}\text { Hairless patch. } \\
\text { Carpal joint }\end{array}$ & $\begin{array}{l}\text { Medium swelling }(<2.5 \mathrm{~cm}) . \\
\text { May have hairless patch. }\end{array}$ & $\begin{array}{l}\text { Major swelling }(>2.5 \mathrm{~cm}) \text { with } \\
\text { or whout lesion or hairless } \\
\text { patch. }\end{array}$ \\
\hline
\end{tabular}


the Canadian farms, we used HOBO Pendant G Acceleration Data Loggers (Onset Computer Corporation, Pocasset, MA, USA; as validated by Ledgerwood et al., 2010), attached with Vet-Wrap (CoFlex, Andover Coated Products Inc., Salisbury, MA), whereas on the US farms we used IceQube pedometers, with the straps provided (IceRobotics, Edinburgh, Scotland). Measures of lying and standing behavior simultaneously derived from the HOBO and IceTag accelerometers have been shown to be strongly correlated (Mattachini et al., 2013). In both cases, devices were programmed to record the position of the cow (lying or standing) at 1-min intervals for 4 consecutive days as described by Vasseur et al. (2012). Recording was set to begin at $2350 \mathrm{~h}$ on the day of the first farm visit. During the second farm visit, all of the data loggers were removed and the data were downloaded.

\section{Data Analysis}

Descriptive Analysis. The data were entered into a relational database (Microsoft Access 2010, Microsoft Corp., Redmond, WA), and then exported to Excel files (Microsoft Excel 2010, Microsoft Corp.). Stata/IC 12 (StataCorp LP, College Station, TX) was used for all analyses. Cows were categorized as being lame if they had an obvious limp and were categorized as having a hock lesion or knee lesion if they had a score of at least 2 on at least one leg. Because of missing data, the number of cows on each farm varied from measure to measure. Thus, we present $\mathrm{n}$ for each test. Data on parity were only obtained from 34 farms and on DIM from 35 farms. Parity was categorized as 1,2 , and $\geq 3$, and DIM was categorized as month of lactation (1 to $\geq 8$ ). Gait scoring was not performed for one farm due to failure during video recording. The odds ratios ( OR) for lameness to be associated with presence of knee and hock lesions were calculated and evaluated using a Pearson $\chi^{2}$ test.

Durations of individual lying bouts were computed using Excel macros (Microsoft Corp.), and the sum of lying time $(\mathrm{h} / \mathrm{d})$, frequency of lying bouts $(\mathrm{n} / \mathrm{d})$, and mean duration of lying bouts $(\mathrm{min} / \mathrm{d})$ was calculated for each day of observation. Data were then averaged over the 4-d observation period, and the median daily lying time (h/d), median frequency of lying bouts (n/d), and median duration of lying bouts ( $\mathrm{min} /$ bout) were calculated for each cow. Cows missing $2 \mathrm{~d}$ of lying data or more were excluded from further analysis. Two cows had extremely high values on lying bout frequency (48 and 54 lying bouts/d). These were excluded because it is likely that the accelerometer did not work properly, leaving lying time records from 1,377 cows for further analysis.
Multivariable Modeling. Single variables were first screened for their association with the 3 measures of lying time through simple linear regression analysis. Three multivariable linear mixed models were then constructed to study the effect of lameness, knee lesions, hock lesions, and BCS on the daily duration of lying down, applying the XTMIXED procedure in Stata (StataCorp LP). Cow within farm was used as the observational unit. Initially, empty models were tested to estimate the random effects of herd and geographic location (Quebec, Ontario, British Columbia, Alberta, and Michigan). Both were found to be significant (herd, $P<0.001$; geographic location, $P=0.02$ ), but the variation explained at the level of geographic area was less than $0.1 \%$. Therefore, only the random effect of herd was forced into the models for different measures of lying time. Presence or absence of lameness, knee lesions, and hock lesions were forced in as the main predictor in one model each. Other variables with $P \leq$ 0.25 in the initial screening of single variables were also selected for further analysis. As a result, the variables $\operatorname{BCS}(\leq 2.25,2.5,2.75,3.0,3.25, \geq 3.5)$, parity $(1,2$, $\geq 3)$, and month of lactation $(1,2,3,4,5,6-7, \geq 8)$ were all entered to the multivariable models as fixed effects. Variables were checked for collinearity by computing Pearson correlations between BCS and month of lactation, BCS and parity, and parity and month of lactation, but none were highly correlated $(|\mathrm{r}| \leq 0.60)$. Multivariable models were constructed using manual backward stepwise elimination and retaining variables with $P \leq 0.05$. The main predictor (lameness, knee lesion, hock lesions) was kept even if $P>0.05$. Finally, previously excluded variables were forced into the model again and retained if $P \leq 0.05$ or if they were judged to confound the main predictor variable (changed its estimates by $>15 \%$ ). One-way interactions with the variable of interest and all other independent variables in the final models were tested, but none were found significant $(P>0.05)$. The models were validated by visual inspection of residual plots and by examination of outliers.

The effect of lameness, knee lesions, and hock lesions on the lying bout frequency and average lying bout duration were also analyzed. The outcome variables "frequency of lying bouts" and "mean lying bout duration" were square-root transformed to obtain close to normal distribution. Presence or absence of lameness, knee lesions, and hock lesions were forced in as the main predictor in one model each for both outcomes (6 models in total). Again the XTMIXED procedure in Stata was applied, testing remaining variables with $P$ $\leq 0.25$ in the initial screening as described above, and again, the random effect of herd was included. Averaged predicted margins (back transformed) and their 
standard errors were calculated for lame and nonlame cows. We found no reasons to exclude any outliers and the fit of all final models were considered satisfactory.

\section{RESULTS}

Cows $(\mathrm{n}=1,377)$ spent a median duration of 11.4 $\mathrm{h} / \mathrm{d}$ lying down $(25 \mathrm{th}-75$ th percentile $=9.7-12.9 \mathrm{~h})$, with a lying bout frequency of 9.5 bouts/d (25th-75th percentile $=7.5-12$ bouts $/ \mathrm{d}$ ) and a median bout duration of $71 \mathrm{~min}(25 \mathrm{th}-75 \mathrm{th}$ percentile $=58-87 \mathrm{~min} /$ bout; Figure 1). However, large differences were found among cows in all 3 measures of lying behavior (Figure 1).

Gait scoring was done on 1,341 cows. Of these, $15.1 \%$ were lame $(\mathrm{n}=203)$ and the median daily lying time of lame cows was $11.7 \mathrm{~h} / \mathrm{d}$ (25th-75th percentile $=9.7$ 13.6). Knee lesions (score 2 or 3 ) were found in $27.1 \%$ of the animals with records on both knees (340 of 1,256 cows) and hock lesions were found in $30.8 \%$ of scored animals (421 of 1,366 cows). The median daily lying time was $11.5 \mathrm{~h} / \mathrm{d}$ (25th-75th percentile $=9.7-13.0)$ among cows with knee lesions and $11.0 \mathrm{~h} / \mathrm{d}$ (25th-75th percentile $=9.2-12.6$ ) among cows with hock lesions. Lameness was associated with both presence of knee lesions $(\mathrm{OR}=1.8, P<0.001)$ and hock lesions (OR $=1.5, P=0.02$ ). In animals with complete records of gait, knee, and hock scores, $50.0 \%$ were uninjured (not lame or having any type of lesion, $\mathrm{n}=578$ of 1,157 cows).

Table 4 shows the result of the univariable screening of variables. In these analyses, lameness was associated with a longer daily duration of lying down, and fewer and longer lying bouts. Presence of hock lesions was associated with shorter daily duration and a shorter mean duration of lying bouts. Presence of knee lesions was associated with longer mean bout duration but not the lying bout frequency or daily duration of lying time.

In the multivariable analysis, presence of lameness was associated with a $0.6 \mathrm{~h}$ longer daily duration of lying down $(P=0.001$, Table 5$)$. Lying time was also longer with higher BCS, higher parity, and later month of lactation. Cows with BCS $\geq 3.5$ lay down on average $1 \mathrm{~h} / \mathrm{d}$ longer than cows with BCS $\leq 2.25$. Older cows (parity $\geq 3$ ) spent about $0.5 \mathrm{~h}$ more time lying than parity 1 cows. Cows within the first month of lactation lay down less than later in lactation. The random effect of herd explained $16 \%$ of the variance between observations whereas the fixed part of the model (lameness, BCS, parity, and month of lactation) explained $8 \%\left(\mathrm{r}^{2}\right.$ $=0.08$, calculated when excluding the random effect of herd).

Although lame cows spent more time lying down, their frequency of lying bouts was lower $(P=0.02$, Table 6$)$ but their lying bouts lasted longer $(P<0.001$,
Table 7) than those of nonlame cows. The multivariable models predicted (back transformed) that a lame cow in general would lay down 9.3 times a day and would stay in a lying position for $78 \mathrm{~min} /$ bout (Table
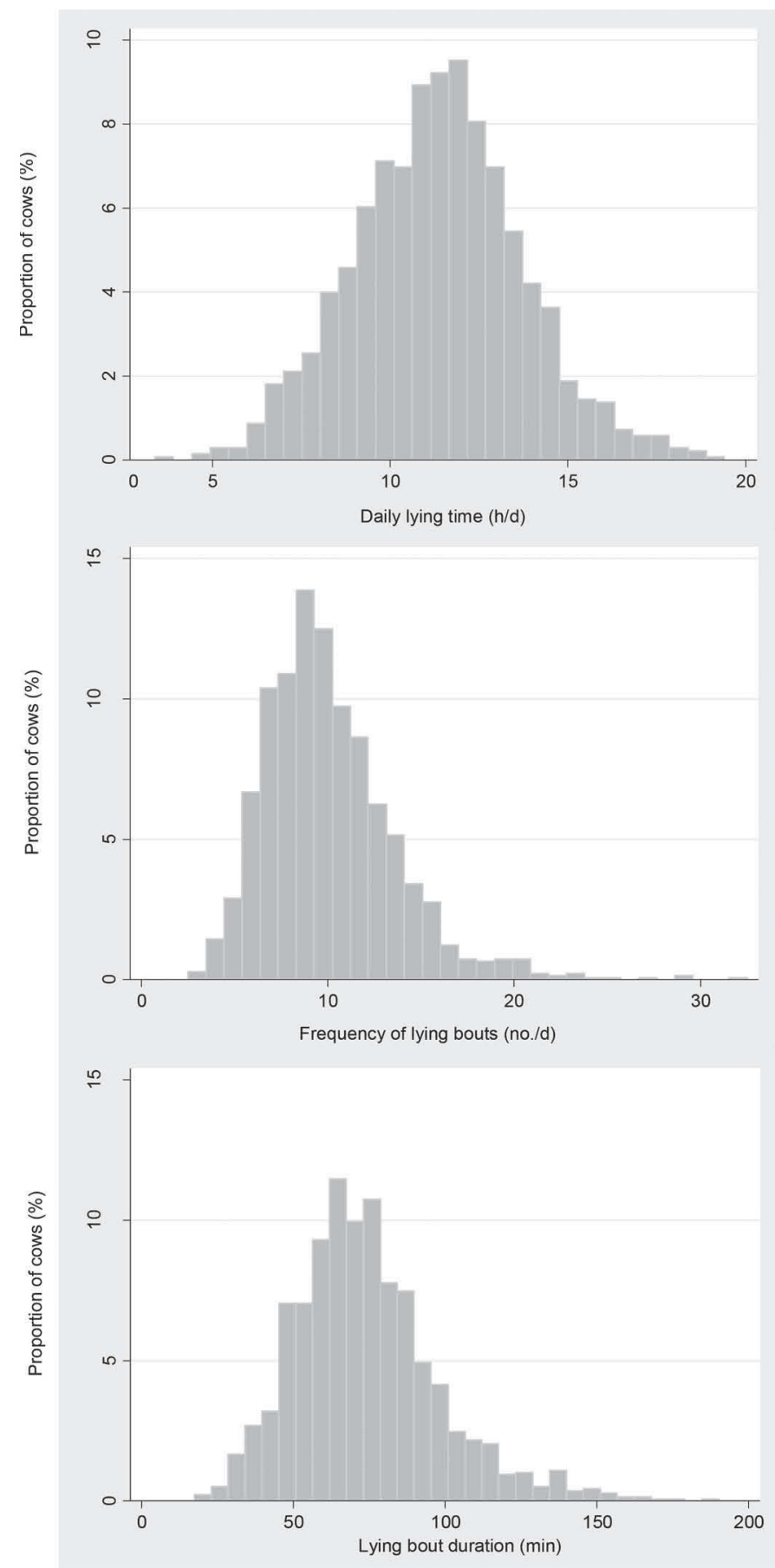

Figure 1. Frequency distribution (\% of cows) of the daily lying time $(\mathrm{h} / \mathrm{d}$; upper panel), the daily frequency of lying bouts $(\mathrm{n} / \mathrm{d}$; middle panel), and the mean lying bout duration (min; lower panel) in 1,377 cows from 36 commercial automated milking system (AMS) farms. 
WESTIN ET AL.

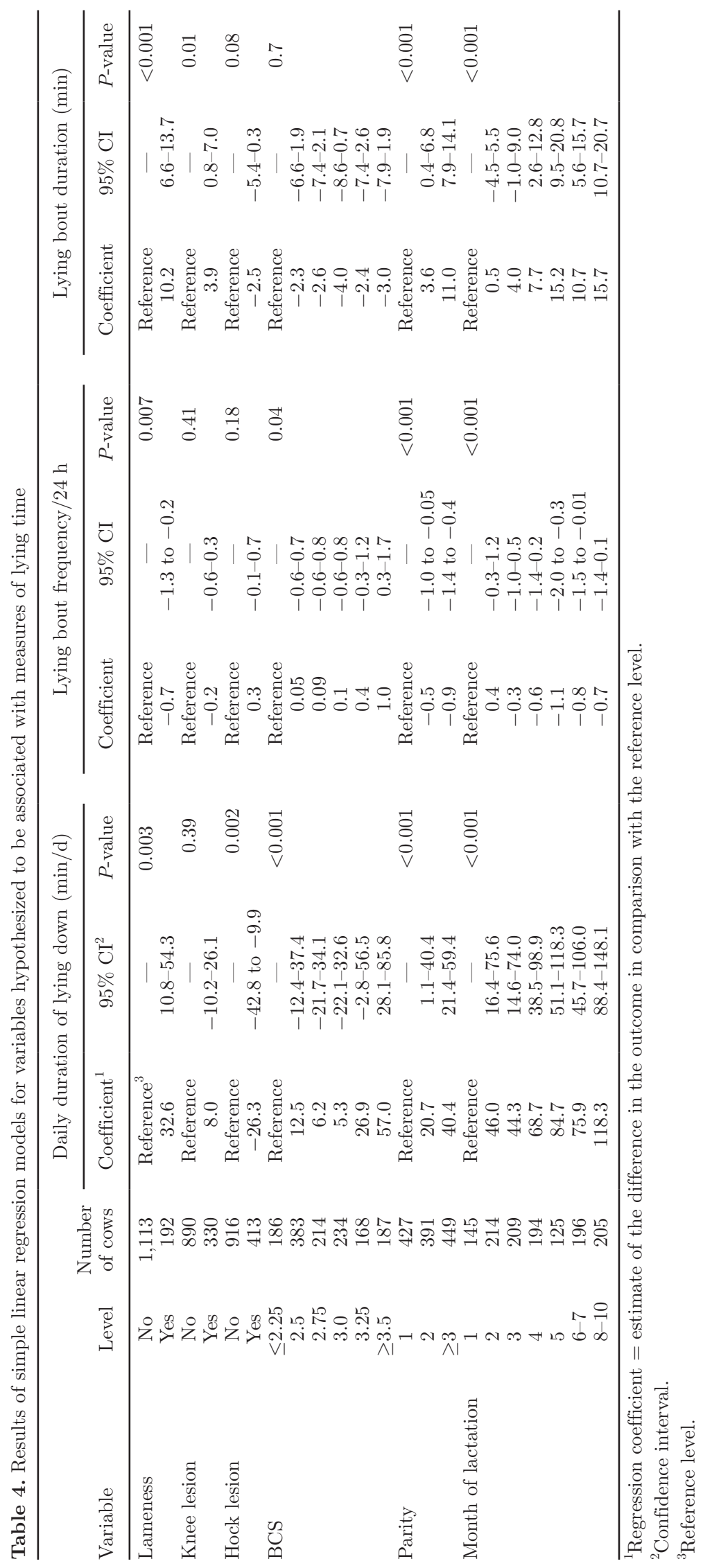


Table 5. Results of a linear mixed-effects model $^{1}$ on daily duration of lying down $(\mathrm{min} / \mathrm{d})$ in relation to presence of lameness, BCS, parity, and month of lactation in 1,175 cows on 33 farms

\begin{tabular}{|c|c|c|c|c|c|}
\hline Variable & Level & Coefficient & $\mathrm{SE}$ & $95 \% \mathrm{CI}$ & $P$-value \\
\hline \multirow[t]{2}{*}{ Lameness } & No & Reference & - & - & - \\
\hline & Yes & 38.0 & 11.0 & $16.3-59.6$ & 0.001 \\
\hline \multirow[t]{6}{*}{ BCS } & $\leq 2.25$ & Reference & - & - & - \\
\hline & 2.5 & 23.5 & 12.5 & -0.9 to 48.0 & 0.06 \\
\hline & 2.75 & 17.6 & 14.9 & $-11.6-46.7$ & 0.24 \\
\hline & 3.0 & 25.8 & 15.3 & $-4.2-55.8$ & 0.09 \\
\hline & 3.25 & 40.4 & 16.8 & $7.4-73.3$ & 0.02 \\
\hline & $\geq 3.5$ & 60.6 & 16.4 & $28.5-92.7$ & $<0.001$ \\
\hline \multirow[t]{3}{*}{ Parity } & 1 & Reference & - & - & - \\
\hline & 2 & 11.6 & 9.8 & $-7.6-30.7$ & 0.24 \\
\hline & $\geq 3$ & 28.7 & 9.6 & $9.8-47.5$ & 0.003 \\
\hline \multirow[t]{7}{*}{ Month of lactation } & 1 & Reference & - & - & - \\
\hline & 2 & 42.5 & 14.7 & $13.7-71.4$ & 0.004 \\
\hline & 3 & 63.8 & 14.8 & $34.8-92.9$ & $<0.001$ \\
\hline & 4 & 69.0 & 15.1 & $39.3-98.7$ & $<0.001$ \\
\hline & 5 & 105.4 & 16.9 & $72.4-138.5$ & $<0.001$ \\
\hline & $6-7$ & 96.3 & 15.5 & $66.0-126.6$ & $<0.001$ \\
\hline & $\geq 8$ & 107.5 & 15.7 & $76.7-138.2$ & $<0.001$ \\
\hline Intercept & & 566.6 & 19.8 & $527.8-605.5$ & $<0.001$ \\
\hline
\end{tabular}

${ }^{1}$ Herd included as a random effect.

Table 6. Results of a linear mixed-effects model ${ }^{1}$ on daily lying bout frequency (n/d; square root transformed) in relation to presence of lameness and parity in 1,196 cows on 33 farms

\begin{tabular}{|c|c|c|c|c|c|}
\hline Variable & Level & Coefficient & $\mathrm{SE}$ & $95 \%$ CI & $P$-value \\
\hline Lameness & $\begin{array}{l}\text { No } \\
\text { Yes }\end{array}$ & $\begin{array}{l}\text { Reference } \\
-0.09\end{array}$ & $\overline{0.04}$ & $-0.18--0.01$ & $\overline{0.02}$ \\
\hline Parity & $\begin{array}{r}1 \\
2 \\
\geq 3\end{array}$ & $\begin{array}{c}\text { Reference } \\
-0.10 \\
-0.13\end{array}$ & $\begin{array}{l}\overline{-} \\
0.04 \\
0.04\end{array}$ & $\begin{array}{c}- \\
-0.17--0.03 \\
-0.20--0.06\end{array}$ & $\begin{array}{r}- \\
0.005 \\
<0.001\end{array}$ \\
\hline Intercept & & 3.23 & 0.04 & $3.14-3.31$ & $<0.001$ \\
\hline
\end{tabular}

${ }^{1}$ Herd included as a random effect.

Table 7. Result of a linear mixed-effects model $^{1}$ on average lying bout duration (min; square root transformed) in relation to presence of lameness, parity, and month of lactation in 1,178 cows on 33 farms

\begin{tabular}{lccccc}
\hline Variable & Level & Coefficient & SE & $95 \%$ CI & $P$-value \\
\hline Lameness & No & Reference & - & - & - \\
\multirow{2}{*}{ Parity } & Yes & 0.44 & 0.10 & $0.19-0.59$ & $<0.001$ \\
& 1 & Reference & - & - & - \\
Month of lactation & 2 & 0.28 & 0.09 & $0.15-0.50$ & 0.001 \\
& $\geq 3$ & 0.49 & 0.08 & $0.36-0.70$ & $<0.001$ \\
& 1 & Reference & - & - & - \\
& 2 & 0.002 & 0.13 & $-0.24-0.27$ & 0.94 \\
& 3 & 0.28 & 0.13 & $0.007-0.53$ & 0.043 \\
& 4 & 0.44 & 0.14 & $0.14-0.68$ & 0.003 \\
Intercept & 5 & 0.86 & 0.15 & $0.55-1.15$ & $<0.001$ \\
& $6-7$ & 0.57 & 0.14 & $0.26-0.81$ & $<0.001$ \\
& $\geq 8$ & 0.72 & 0.14 & $0.40-0.98$ & $<0.001$ \\
& & 7.75 & 0.14 & $7.46-8.02$ & $<0.001$ \\
\hline
\end{tabular}

${ }^{1}$ Herd included as a random effect. 
8), whereas nonlame cows would lie down 9.9 times for $71 \mathrm{~min} /$ bout. Lying bout frequency and mean duration of each lying bout were also influenced by parity with fewer and longer lying bouts in older animals. Month of lactation only affected the duration of lying bouts with longer lying bouts from the third month and onward compared with cows in the first month of lactation. The BCS did not affect the frequency or mean duration of lying bouts. The random effect of herd explained $13 \%$ of the variation of lying bout frequency and $16 \%$ of the bout duration. The variables in the fixed part of the models explained 2 and $11 \%$, respectively $\left(\mathrm{r}^{2}\right.$ calculated when excluding the random effect of herd).

The presence of knee lesions and hock lesions did not influence any measure of lying time in the multivariable models.

\section{DISCUSSION}

Our results show that the daily duration of time spent lying down varied greatly among cows on AMS farms, with lame cows lying down for longer in fewer, longer bouts. Increased lying time was also associated with increased parity, later stage of lactation, and higher BCS.

The median total lying time of cows $(11.4 \mathrm{~h} / \mathrm{d})$ fell within the range of that previously reported on commercial AMS farms in Ontario, Canada $(9.3-13.9 \mathrm{~h} / \mathrm{d}$, DeVries et al., 2011; Deming et al., 2013) and Switzerland (9.4-11.5 h, Helmreich et al., 2014). The Canadian Code of Practice for Dairy Cattle (DFC-NFACC, 2009) recommends that cows should lie down comfortably for at least $12 \mathrm{~h}$ per day and a high proportion of the cows on the participating AMS farms in the current study met this target. However, a large variation was present

Table 8. Least squares means (and $95 \% \mathrm{CI}$ ) of lying time (h/d), bout frequency (n/d), and mean bout duration (min/bout) for lame and nonlame cows

\begin{tabular}{lccc}
\hline Variable & Nonlame & Lame & $P$-value \\
\hline Lying time $(\mathrm{h} / \mathrm{d})^{1}$ & 11.3 & 11.9 & 0.001 \\
& $(10.9-11.6)$ & $(11.3-12.3)$ & \\
Bout frequency $(\mathrm{n} / \mathrm{d})^{2}$ & 9.9 & 9.3 & 0.02 \\
& $(9.5-10.4)$ & $(8.7-9.9)$ & \\
Bout duration (min/bout) & 70.7 & 78.3 & $<0.001$ \\
& $(67.6-73.8)$ & $(74.0-82.8)$ & \\
\hline
\end{tabular}

${ }^{1}$ Values are from mixed-effects linear models accounting for fixed effects of parity, month of lactation, and BCS, and a random effect of farm.

${ }^{2}$ Values are from mixed-effects linear models accounting for fixed effects of parity and a random effect of farm. Back-transformed least squares means (95\% CI) where square root transformation was applied to the variable.

${ }^{3}$ Values are from mixed-effects linear models accounting for fixed effects of parity, month of lactation, and a random effect of farm. Backtransformed least squares means (95\% CI) where square root transformation was applied to the variable. between individual cows in all measures of lying time. Whereas the flow of cows in AMS farms is very complex and affected by factors such as competition for access to the AMS unit and barn design (forced versus free traffic), AMS nonetheless facilitate the cow establishing her own daily schedule (Jacobs and Siegford, 2012), which may account for the large variation in lying times between individual cows. In a previous study examining feeding patterns on AMS farms, individual differences between cows was found to account for 84 to $98 \%$ of the random variation in feeding patterns and it was concluded that cows develop consistent individual feeding and drinking patterns (Melin et al., 2005). Thus, this may also be true for patterns of resting behavior.

Some of the variation in lying time between cows was related to parity and stage of lactation, with older cows and cows at a later stage of lactation lying down in longer bouts, which is in agreement with previous research (Norring et al., 2012; Vasseur et al., 2012; Charlton et al., 2015). Being in estrus can reduce lying time (Silper et al., 2015), and because it is likely that some of the participating cows were in heat during the study period, this may also account for some of the variation in lying times.

Lameness was associated with greater lying time, with lame cows lying down for $0.6 \mathrm{~h}$ longer per day in fewer, longer lying bouts. These findings are in agreement with reports from several studies performed on free-stall farms. Chapinal et al. (2009) reported that cows with sole ulcers spent $>1 \mathrm{~h} / \mathrm{d}$ more lying down compared with cows without hoof lesions (13.8 vs. 12.6 $\mathrm{h} / \mathrm{d}$, respectively). In a study by Blackie et al. (2011), lame cows spent approximately $2 \mathrm{~h} / \mathrm{d}$ more time lying down than sound cows (13.0 vs. $10.9 \mathrm{~h} / \mathrm{d}$, respectively). Once animals become lame, a prolonged time spent standing, resulting in increased loading of the claw, may increase the severity of the lesion (Galindo and Broom, 2000). A longer lying time in lame cows is likely to be beneficial because this may facilitate recovery (Cook and Nordlund, 2009). Whether the $0.6 \mathrm{~h}$ of additional daily rest is sufficient to promote recovery from lameness is yet to be determined.

Other studies have shown that both lying time per $s e$, and lying time in association with lameness are also dependent on housing conditions such as stall surface. Ito et al. (2010) found that in farms with deep bedded systems, severely lame cows spent $12.8 \mathrm{~h} / \mathrm{d}$ lying down compared with $11.2 \mathrm{~h} / \mathrm{d}$ for cows that were not severely lame, but no difference was found among cows in farms using mattress stalls. Within the current study, cows were housed on a variety of stall bases and this may account for the relatively small (but significant) difference in lying time found between lame and nonlame cows. In AMS farms, milking frequency, frequency of 
feed push-up, and feed bunk space have been found to be associated with lying time (DeVries et al., 2011; Deming et al., 2013; Helmreich et al., 2014). Thus, these factors may have been influential in the present study.

Due to the large variation between individuals and the low proportion of variance explained by the animalbased measures in our studied models (2 to $11 \%$ ), it seems likely that using a single assessment of lying time is not a very useful tool to identify lame cows on a farm. In the Canadian Code of Practice for Dairy Cattle (DFC-NFACC, 2009), lying time is regarded as an indicator of cow comfort. However, although improving the quality of the lying area increases lying time (Rushen et al., 2007; Tucker et al., 2009), our study indicates that lameness will also increase the time spent lying down. Thus, to use lying time as the sole parameter to evaluate cow comfort is not advisable. Consideration of both lameness prevalence and lying times of nonlame cows may provide a more reliable indicator of cow comfort on the herd level.

Charlton et al. (2015) found a relationship between lying time and hock and knee lesions in tie stall farms, with injured cows spending about 20 to 30 min less time lying down than cows without lesions. In the univariable models in our study, hock injuries were similarly associated with reduced daily lying time, although knee injuries were not. Hock injuries were associated with shorter lying bouts, whereas knee injuries were associated with longer lying bouts. However, when farm identity, parity, and stage of lactation were included in the multivariable model, the effect of hock and knee lesions was no longer significant. Housing and management factors such as lack of bedding and hard floors are known to increase the prevalence of hock and knee lesions (Kester et al., 2014; Zaffino Heyerhoff et al., 2014) as well as to reduce lying time in dairy cows (Rushen et al., 2007; Tucker et al., 2009). Herd-level analysis including housing and management factors is needed to better understand the relationship between lying time and knee and hock lesions.

On average, thin cows (BCS $\leq 2.25)$ in the present study lay down $1 \mathrm{~h} / \mathrm{d}$ less than cows with high BCS $(\geq 3.5)$. Bewley et al. (2010) also observed a trend of increasing lying times with increasing BCS although it was not significant in their relatively small data set of only 77 cows. This may be due to the lack of cushioning (lower body fat) when the thin cows are lying on hard surfaces. Additionally, social competition can increase variation in lying behavior, with subordinate cows experiencing more displacements from lying stalls (Fregonesi et al., 2007), causing a reduced lying time for low-ranking individuals (Galindo and Broom, 2000). In AMS farms, cows also have to compete for access to the AMS and low-ranked animals in general spend more time in the waiting area (Melin et al., 2006), which may reduce the time available for rest. Simulations of waiting time show that low-ranking cows may be waiting about $1 \mathrm{~h}$ on a typical day and up to $7 \mathrm{~h}$ in crowded situations (i.e., where all cows have to pass through the robot to access pasture; Halachmi, 2009). In this study we did not evaluate the social rank of the cows, but an association between low body mass and low social rank has been observed previously (Hohenbrink and Meinecke-Tillmann, 2012; Landaeta-Hernández et al., 2013). A third plausible explanation is that the thin cows in the study had higher milk yields and therefore spent more time standing eating, compared with cows producing less milk with possibly higher BCS.

\section{CONCLUSIONS}

The aim of this study was to describe the variation in lying times of dairy cows in AMS farms and to relate the individual lying times to lameness, presence of hock and knee lesions and to BCS. A large individual variation in daily lying time was observed, with lame cows lying down $0.6 \mathrm{~h} / \mathrm{d}$ more in fewer, longer bouts. Increased lying time was also associated with increased parity, later stage of lactation and higher BCS. No associations were found between measures of lying time and leg lesions. However, these cow-related factors only explained a small percentage of the variation between cows in lying time, suggesting that farm level factors, and other cow level factors are important sources of variability.

\section{ACKNOWLEDGMENTS}

We thank the participating farmers from the United States and Canada and the collaborators, technicians, students, and co-op students from Michigan State University, the University of British Columbia, University of Calgary, University of Guelph, Laval University, and Valacta Inc. We thank Jenny Gibbons (DairyCo UK) and Gemma Charlton (Harper Adams University, Newport, UK) for invaluable help with establishing the database. This study was funded by the Dairy Farmers of Canada (Ottawa, ON, Canada), the Canadian Dairy Commission (Ottawa, ON, Canada), Agriculture and Agri-Food Canada (Ottawa, ON, Canada), as part of the Dairy Science Cluster initiative, Agriculture and Agri-Food Canada and the BC Ministry of Agriculture (Victoria, BC, Canada) through the Canada-BC Agri-Innovation Program under Growing Forward 2, a federal-provincial-territorial initiative (delivered by the Investment Agriculture Foundation of BC), Alberta Milk (Edmonton, AB, Canada), the Alberta Livestock 
and Meat Agency (Edmonton, AB, Canada), and the Natural Sciences and Engineering Research Council of Canada (Ottawa, ON, Canada). We also thank the Michigan State University Department of Animal Science for supporting this research through an award from the Elwood Kirkpatrick Dairy Research Science Endowment to Janice Siegford (East Lansing, MI).

\section{REFERENCES}

Bach, A., M. Dinarés, M. Devant, and X. Carré. 2007. Associations between lameness and production, feeding and milking attendance of Holstein cows milked with an automatic milking system. J. Dairy Res. 74:40-46.

Bewley, J. M., R. E. Boyce, J. Hockin, L. Munksgaard, S. D. Eicher, M. E. Einstein, and M. M. Schutz. 2010. Influence of milk yield, stage of lactation, and body condition on dairy cattle lying behaviour measured using an automated activity monitoring sensor. J. Dairy Res. 77:1-6.

Blackie, N., J. Amory, E. Bleach, and J. Scaife. 2011. The effect of lameness on lying behaviour of zero grazed Holstein dairy cattle. Appl. Anim. Behav. Sci. 134:85-91. http://dx.doi.org/10.1016/j. applanim.2011.08.004.

Borderas, T. F., A. Fournier, J. Rushen, and A. M. B. de Passillé 2008. Effect of lameness on dairy cows' visits to automatic milking systems. Can. J. Anim. Sci. 88:1-8.

Chapinal, N., A. M. de Passillé, D. M. Weary, M. A. G. von Keyserlingk, and J. Rushen. 2009. Using gait score, walking speed, and lying behavior to detect hoof lesions in dairy cows. J. Dairy Sci. 92:4365-4374. http://dx.doi.org/10.3168/jds.2009-2115.

Charlton, G. L., V. Bouffard, J. Gibbons, E. Vasseur, D. B. Haley, D. Pellerin, J. Rushen, and A. M. de Passillé. 2015. Can automated measures of lying time help assess lameness and leg lesions on tie-stall dairy farms? Appl. Anim. Behav. Sci. http://dx.doi. org/10.1016/j.applanim.2015.02.011. In press.

Charlton, G. L., D. B. Haley, J. Rushen, and A. M. de Passillé. 2014. Stocking density, milking duration, and lying times of lactating cows on Canadian freestall dairy farms. J. Dairy Sci. 97:26942700. http://dx.doi.org/10.3168/jds.2013-6923.

Cook, N. B., and K. V. Nordlund. 2009. The influence of the environment on dairy cow behavior, claw health and herd lameness dynamics. Vet. J. 179:360-369. http://dx.doi.org/10.1016/j. tvjl.2007.09.016.

Deming, J. A., R. Bergeron, K. E. Leslie, and T. J. DeVries. 2013. Associations of housing, management, milking activity, and standing and lying behavior of dairy cows milked in automatic systems. J. Dairy Sci. 96:344-351. http://dx.doi.org/10.3168/jds.2012-5985.

DeVries, T. J., J. A. Deming, J. Rodenburg, G. Seguin, K. E. Leslie, and H. W. Barkema. 2011. Association of standing and lying behavior patterns and incidence of intramammary infection in dairy cows milked with an automatic milking system. J. Dairy Sci. 94:3845-3855. http://dx.doi.org/10.3168/jds.2010-4032.

DFC-NFACC (Dairy Farmers of Canada and the National Farm Animal Care Council). 2009. Code of Practices for the Care and Handling of Dairy Cattle. Dairy Farmers of Canada, Ottawa, Ontario, Canada.

Elanco Animal Health. 1996. Body condition scoring. Bulletin AI 8478, Rev. 9/96. Elanco Animal Health, Indianapolis, IN.

Ferguson, J. D., D. T. Galligan, and N. Thomsen. 1994. Principal descriptors of body condition score in Holstein cows. J. Dairy Sci. 77:2695-2703. http://dx.doi.org/10.3168/jds.S00220302(94)77212-X.

Flower, F. C., and D. M. Weary. 2006. Effect of hoof pathologies on subjective assessments of dairy cow gait. J. Dairy Sci. 89:139-146. http://dx.doi.org/10.3168/jds.S0022-0302(06)72077-X.

Fregonesi, J. A., C. B. Tucker, and D. M. Weary. 2007. Overstocking reduces lying time in dairy cows. J. Dairy Sci. 90:3349-3354. http://dx.doi.org/10.3168/jds.2006-794.
Galindo, F., and D. M. Broom. 2000. The relationships between social behaviour of dairy cows and the occurrence of lameness in three herds. Res. Vet. Sci. 69:75-79. http://dx.doi.org/10.1053/ rvsc.2000.0391.

Gibbons, J., E. Vasseur, J. Rushen, and A. M. de Passillé. 2012. A training programme to ensure high repeatability of injury scoring of dairy cows. Anim. Welf. 21:379-388.

Green, L. E., J. N. Huxley, C. Banks, and M. J. Green. 2014. Temporal associations between low body condition, lameness and milk yield in a UK dairy herd. Prev. Vet. Med. 113:63-71. http://dx.doi. org/10.1016/j.prevetmed.2013.10.009.

Halachmi, I. 2009. Simulating the hierarchical order and cow queue length in an automatic milking system. Biosystems Eng. 102:453460. http://dx.doi.org/10.1016/j.biosystemseng.2009.01.010.

Helmreich, S., R. Hauser, T. Jungbluth, B. Wechsler, and L. Gygax 2014. Time-budget constraints for cows with high milking frequency on farms with automatic milking systems. Livest. Sci. 167:315322. http://dx.doi.org/10.1016/j.livsci.2014.06.014.

Hohenbrink, S., and S. Meinecke-Tillmann. 2012. Influence of social dominance on the secondary sex ratio and factors affecting hierarchy in Holstein dairy cows. J. Dairy Sci. 95:5694-5701. http:// dx.doi.org/10.3168/jds.2011-5281.

Ito, K., M. A. G. von Keyserlingk, S. J. LeBlanc, and D. M. Weary. 2010. Lying behavior as an indicator of lameness in dairy cows. J. Dairy Sci. 93:3553-3560. http://dx.doi.org/10.3168/jds.2009-2951.

Ito, K., D. M. Weary, and M. A. G. von Keyserlingk. 2009. Lying behavior: Assessing within- and between-herd variation in freestall-housed dairy cows. J. Dairy Sci. 92:4412-4420. http://dx.doi. org/10.3168/jds.2009-2235.

Jacobs, J. A., and J. M. Siegford. 2012. Invited review: The impact of automatic milking systems on dairy cow management, behavior, health, and welfare. J. Dairy Sci. 95:2227-2247. http://dx.doi. org/10.3168/jds.2011-4943.

Jensen, M. B., L. J. Pedersen, and L. Munksgaard. 2005. The effect of reward duration on demand functions for rest in dairy heifers and lying requirements as measured by demand functions. Appl. Anim. Behav. Sci. 90:207-217. http://dx.doi.org/10.1016/j. applanim.2004.08.006

Kester, E., M. Holzhauer, and K. Frankena. 2014. A descriptive review of the prevalence and risk factors of hock lesions in dairy cows. Vet. J. 202:222-228. http://dx.doi.org/10.1016/j.tvjl.2014.07.004.

Kielland, C., L. E. Ruud, A. J. Zanella, and O. Østerås. 2009. Prevalence and risk factors for skin lesions on legs of dairy cattle housed in freestalls in Norway. J. Dairy Sci. 92:5487-5496. http://dx.doi. org/10.3168/jds.2009-2293.

Landaeta-Hernández, A. J., D. O. Rae, M. Kaske, and L. F. Archbald. 2013. Factors influencing social organization in postpartum Angus cows under confinement. Effect on cow-calf weight change. Livest. Sci. 152:47-52. http://dx.doi.org/10.1016/j.livsci.2012.11.019.

Ledgerwood, D. N., C. Winckler, and C. B. Tucker. 2010. Evaluation of data loggers, sampling intervals, and editing techniques for measuring the lying behavior of dairy cattle. J. Dairy Sci. 93:51295139. http://dx.doi.org/10.3168/jds.2009-2945.

Mattachini, G., E. Riva, C. Bisaglia, J. C. A. M. Pompe, and G. Provolo. 2013. Methodology for quantifying the behavioral activity of dairy cows in freestall barns. J. Anim. Sci. 91:4899-4907.

Melin, M., G. G. N. Hermans, G. Pettersson, and H. Wiktorsson. 2006. Cow traffic in relation to social rank and motivation of cows in an automatic milking system with control gates and an open waiting area. Appl. Anim. Behav. Sci. 96:201-214. http://dx.doi. org/10.1016/j.applanim.2005.06.013.

Melin, M., H. Wiktorsson, and L. Norell. 2005. Analysis of feeding and drinking patterns of dairy cows in two cow traffic situations in automatic milking systems. J. Dairy Sci. 88:71-85. http://dx.doi. org/10.3168/jds.S0022-0302(05)72664-3.

Miguel-Pacheco, G. G., J. Kaler, J. Remnant, L. Cheyne, C. Abbott, A. P. French, T. P. Pridmore, and J. N. Huxley. 2014. Behavioural changes in dairy cows with lameness in an automatic milking system. Appl. Anim. Behav. Sci. 150:1-8. http://dx.doi. org/10.1016/j.applanim.2013.11.003. 
Munksgaard, L., M. B. Jensen, L. J. Pedersen, S. W. Hansen, and L. Matthews. 2005. Quantifying behavioural priorities - effects of time constraints on behaviour of dairy cows, Bos taurus. Appl. Anim. Behav. Sci. 92:3-14. http://dx.doi.org/10.1016/j. applanim.2004.11.005.

Munksgaard, L., and H. B. Simonsen. 1996. Behavioral and pituitary adrenal-axis responses of dairy cows to social isolation and deprivation of lying down. J. Anim. Sci. 74:769-778.

Norring, M., A. Valros, and L. Munksgaard. 2012. Milk yield affects time budget of dairy cows in tie-stalls. J. Dairy Sci. 95:102-108. http://dx.doi.org/10.3168/jds.2010-3458.

Randall, L. V., M. J. Green, M. G. G. Chagunda, C. Mason, S. C. Archer, L. E. Green, and J. N. Huxley. 2015. Low body condition predisposes cattle to lameness: An 8-year study of one dairy herd. J. Dairy Sci. 98:3766-3777. http://dx.doi.org/10.3168/jds.2014-8863.

Rushen, J., D. Haley, and A. M. de Passillé. 2007. Effect of softer flooring in tie stalls on resting behavior and leg injuries of lactating cows. J. Dairy Sci. 90:3647-3651. http://dx.doi.org/10.3168/ jds.2006-463.

Silper, B. F., L. Polsky, J. Luu, T. A. Burnett, J. Rushen, A. M. de Passillé, and R. L. A. Cerri. 2015. Automated and visual measurements of estrous behavior and their sources of variation in Holstein heifers II: Standing and lying patterns. Theriogenology 84:333341. http://dx.doi.org/10.1016/j.theriogenology.2014.12.030.

Tucker, C. B., D. M. Weary, M. A. G. von Keyserlingk, and K. A. Beauchemin. 2009. Cow comfort in tie-stalls: Increased depth of shavings or straw bedding increases lying time. J. Dairy Sci. 92:2684-2690. http://dx.doi.org/10.3168/jds.2008-1926.
Vasseur, E., J. Gibbons, J. Rushen, and A. M. de Passillé. 2013. Development and implementation of a training program to ensure high repeatability of body condition scoring of dairy cows. J. Dairy Sci. 96:4725-4737. http://dx.doi.org/10.3168/jds.2012-6359.

Vasseur, E., J. Gibbons, J. Rushen, D. Pellerin, E. Pajor, D. Lefebvre, and A. M. de Passillé. 2015. An assessment tool to help producers improve cow comfort on their farms. J. Dairy Sci. 98:698-708. http://dx.doi.org/10.3168/jds.2014-8224.

Vasseur, E., J. Rushen, D. B. Haley, and A. M. de Passillé. 2012 Sampling cows to assess lying time for on-farm animal welfare assessment. J. Dairy Sci. 95:4968-4977. http://dx.doi.org/10.3168/ jds.2011-5176.

Wagner-Storch, A. M., and R. W. Palmer. 2003. Feeding behavior, milking behavior, and milk yields of cows milked in a parlor versus an automatic milking system. J. Dairy Sci. 86:1494-1502. http:// dx.doi.org/10.3168/jds.S0022-0302(03)73735-7.

Wildman, E. E., G. M. Jones, P. E. Wagner, R. L. Boman, H. F. Troutt Jr., and T. N. Lesch. 1982. A dairy cow body condition scoring system and its relationship to selected production characteristics. J. Dairy Sci. 65:495-501. http://dx.doi.org/10.3168/jds. S0022-0302(82)82223-6.

Zaffino Heyerhoff, J. C., S. J. LeBlanc, T. J. DeVries, C. G. R. Nash, J. Gibbons, K. Orsel, H. W. Barkema, L. Solano, J. Rushen, A. M. de Passillé, and D. B. Haley. 2014. Prevalence of and factors associated with hock, knee, and neck injuries on dairy cows in freestall housing in Canada. J. Dairy Sci. 97:173-184. http:// dx.doi.org/10.3168/jds.2012-6367. 